\title{
A RAPID SCREENING METHOD FOR CUTINASE PRODUCING MICROORGANISMS
}

\author{
Gabriela Alves Macedo*; Tatiana Fontes Pio \\ Faculdade de Engenharia de Alimentos, Laboratório de Bioquímica de Alimentos, Universidade Estadual de Campinas, \\ Campinas, SP, Brasil
}

Submitted: March 09, 2005; Returned to authors for corrections: July 07, 2005; Approved: November 22, 2005

\begin{abstract}
Both cutinase and lipase belong to the esterase group of enzymes (EC 3.1.1.X), which are capable of catalyzing the hydrolysis of ester bonds. Cutinase catalyzes the hydrolysis of cutin, an insoluble biopolyester which is the structural component of plant cuticles. As cutinase is an efficient catalyst in watery or organic media, it is potentially appropriate for the detergent, food and cosmetic industries. The objective of this work was to isolate microorganisms from plants and perform a pre-selection of molds showing esterase producing ability. The selected strains were then submitted to fermentation in media containing cutin. The lipolytic and cutinolytic activities of the supernatant were determined in order to differentiate lipase producers from cutinase-producing strains. The mold strain selected as the best cutinase producer was identified as being Fusarium oxysporium.
\end{abstract}

Key words: cutinase, esterase, microbial enzymes, screening

\section{INTRODUCTION}

Many microorganisms grow on polymeric materials as their sole carbon sources. The use of plant polymers by microorganisms involves the excretion of hydrolytic enzymes. However, it is not known how a polymer, which cannot enter the cell, triggers the production of hydrolytic enzymes. One possibility is that the microbes excrete a basal level of several hydrolytic enzymes, and then the hydrolysis products enter the cell to induce the synthesis of enzymes (11).

Plant-pathogenic fungi gain access to the aerial parts of plants by penetrating into the healthy tissue. Some pathogens such as rust fungi invade the host via the stomata, whereas others penetrate the intact plant leaves with no regard to natural leaves openings. The mechanism by which pathogens break this barrier has been debated for almost a century. Penetration was long thought to be mechanical, but the involvement of cutinolytic enzymes secreted by the invading pathogens has often been postulated (10).

The polyester that protects plant tissue is cutin, which is composed of the following fatty acids: $\omega$-hydroxyfatty acids, dihidroxypalmitic acids, saturated and 12- monounsaturated 18-hydroxy 9, 10-epoxy $\mathrm{C}_{18}$ acids, and saturated and 12monounsaturated 9,10,18- trihydroxy $\mathrm{C}_{18}$ acids (9).

Several phytopathogenic fungi have been reported to produce cutinases which hydrolyze cutin. Several of these fungal cutinases have been purified and characterized. Then, studies based on the use of chemical inhibitors, cutinase specific antibodies and molecular-biology techniques were carried out. It is now clear that cutinases have an important role in the penetration of intact plant surfaces by certain fungi (5).

Like lipase, cutinase belongs to the esterase group (EC 3.1.1.x), which represents a diverse group of hydrolases catalyzing the cleavage and formation of ester bonds. These enzymes are widely distributed in animals, plants and microorganisms. Interest in these enzymes also resides in the fact that they do not require cofactors, are usually fairly stable, act in both hydrolysis and synthetic reactions and are even active in organic solvents (1).

Cutinase is a versatile enzyme showing several interesting properties which can be applied to industrial processes. An enzymatic preparation containing cutinase has been developed to increase the pharmacological effects of agricultural chemicals. Cutinase has been applied as a lipolytic enzyme in laundry and

*Corresponding Author. Mailing address: Faculdade de Engenharia de Alimentos - UNICAMP - Laboratório de Bioquímica de Alimentos - Caixa Postal 6121. 13083-970 Campinas, SP, Brasil. E-mail: gmacedo@fea.unicamp.br 
dishwashing detergents to remove fats. Degradation of plastics, such as the synthetic polyester polycaprolactone, into watersoluble products, has been achieved using cutinase (13).

Other potential uses of cutinases include the hydrolysis of milk fat in the dairy industry, uses in the oleochemistry industry and in the synthesis of structured triglycerides, to optain polymers and surfactants used in personal-care products and pharmaceuticals or agrochemicals containing one or more chiral centers (13).

The objective of this work was to isolate microorganisms from plants and perform a pre-selection of molds showing esterase producing ability, using a fast test in Petri dishes. The selected strains were then submitted to fermentation in media containing cutin. The lipolytic and cutinolytic activities of the supernatant were determined in order to differentiate lipase and cutinase producers from cutinase producers.

\section{MATERIALS AND METHODS}

\section{Isolation and maintaining of cultures}

Samples from plants, fruits, leaves and bark of trees were collected in the field from different areas of São Paulo State, and inoculated into Petri Plates containing PDA (potato dextrose agar) media and incubated at $30^{\circ} \mathrm{C}$. The purified fungi strains obtained were then assembled into assay vials containing PDA medium, and stored in the refrigerator.

\section{Screening for esterase-producing microorganisms}

Isolated fungal strains and fungi from the laboratory culture collections were inoculated into Petri dishes containing triacetin agar (containing the colorant Rodamin B) culture media, and incubated at $30^{\circ} \mathrm{C}$. The species from tested strain were not identified but, only fungi strains were tested.

The formation of a fluorescent halo around a colony during growth, indicated the production of esterase (1).

\section{Cutin extraction}

Ripe apples, oranges, papaya and cucumbers, purchased from the local market, were used to extract cutin. The fruits/ vegetables were peeled and the peels added to a boiling oxalate buffer solution at $\mathrm{pH} 3.5$ for 15 minutes or until be fully devoid of pulp. Then, the peels were filtered, washed, dried at $40^{\circ} \mathrm{C}$, extracted with chloroform-methanol and vacuum-dried. The resulting powder was treated with celullase and pectinase then dissolved in $0.05 \mathrm{M}$ acetate buffer at $\mathrm{pH} 4.0$ for 16 hours at room temperature with agitation, and finally filtered, washed and dried in a vacuum oven at $40^{\circ} \mathrm{C}(8)$.

\section{Growth medium for cutinase production}

All the strains selected as positive esterase producers were inoculated into $10 \mathrm{~mL}$ of a culture media composed as follows: $0.06 \%$ sodium nitrate, $0.06 \%$ potassium fosfate, $0.02 \%$ magnesium sulfate, $0.02 \%$ potassium chloride, $0.01 \%$ hephydrate ferrous sulfate, at $\mathrm{pH} 7.2$, plus $0.1 \%$ glucose or $0.4 \%$ cutin (w/v) as carbon source. The cultures were incubated in a rotary fermentor at $30^{\circ} \mathrm{C}$ and shaken at $100 \mathrm{rpm}$ for 96 hours. After culture development, the tubes were centrifuged at $1070 \mathrm{x} \mathrm{G}$ at $10^{\circ} \mathrm{C}$, for 15 minutes. The cutinase and lipase activities were measured in the supernatants (16).

\section{Cutinase assay}

Cutinase activity was determined spectrophotometrically following the hydrolysis of $p$-nitrophenylbutyrate (PNPB) at $405 \mathrm{~nm}$. An aliquot $(0.070 \mathrm{~mL})$ of the culture supernatant was added to $3.43 \mathrm{~mL}$ of a reaction mixture having the following composition: $0.56 \mathrm{~mL}$ PNPB dissolved in $50 \mathrm{mM}$ phosphate buffer $\mathrm{pH}$ at 7.0 , containing also $0.2 \%$ (N/P) Triton X-100 and $0.43 \mathrm{M}$ tetrahydrofuran. The reaction was monitored for one minute against a blank solution. One unit of cutinolytic activity was defined as the amount of cutinase required to release one micromole of $p$-nitrophenol in one minute under the specified conditions (2).

\section{Lipase assay}

One milliliter samples of the culture supernatant was added to a reaction mixture containing $2 \mathrm{~mL}$ of $0.1 \mathrm{M}$ phosphate buffer at $\mathrm{pH} 7.0$ and $5 \mathrm{~mL}$ of an emulsion having the following composition (v/v): $75 \%$ Arabic gum (7\%) and 25\% olive oil. The solution was incubated at $37^{\circ} \mathrm{C}$ for 30 minutes with shaking at $120 \mathrm{rpm}$. After incubation, the reaction was stopped by additing $15 \mathrm{~mL}$ ethanol:acetone $1: 1(\mathrm{v} / \mathrm{v})$, the fatty acids being released and titrated with $0.05 \mathrm{M}$ sodium hydroxide One unit of lipase activity was defined as the amount of enzyme required to release one $\mu \mathrm{mol}$ of oleic acid in one minute per $\mathrm{mL}$ under the specified conditions (12).

\section{Cultivation conditions \\ Fermentation time}

Strains selected as cutinase producers were inoculated into culture media containing $0.4 \%$ (w/v) cutin as carbon source. The medium was then incubated at $30^{\circ} \mathrm{C}$ with shaking at 100 rpm for 14 days. After 4, 6, 8, 10, 12 and 14 days of incubation, each medium was centrifuged at $10,000 \mathrm{rpm}$ at $10^{\circ} \mathrm{C}$ for 15 minutes and the cutinolytic activity measured in the supernatant (16).

\section{Cutin concentration in the growth medium}

Culture media for cutinase production were prepared to contain $0.2 \% ; 0.4 \% ; 0.8 \%$ and $1.0 \%(\mathrm{w} / \mathrm{v})$ of cutin as carbon source and they were inoculated with the cutinase producer strains. The media were then incubated at $30^{\circ} \mathrm{C}$ with shaking $(100 \mathrm{rpm})$ for a period of 4 days. After full development of the cultures, the culture medium was centrifuged at 10,000 rpm at $10^{\circ} \mathrm{C}$ for 15 minutes and the cutinolytic activity measured in the supernatant (12). 


\section{Procedure for chemical hydrolysis of the cutin}

The cutin powder was suspended in a solution composed of potassium hydroxide in methanol, $1.5 \mathrm{~mol} / \mathrm{L}$ ( $30 \mathrm{mg}$ of cutin in $2 \mathrm{~mL}$ of solution) and shaken at room temperature for $20 \mathrm{~h}$. The mixture was then acidified by adding $1 \mathrm{~mol} \mathrm{~L}^{-1}$ of cloridric acid, extracted twice with chloroform and the organic phase dried by vacuum (7).

\section{Procedure for enzymatic hydrolysis of cutin}

The cutinolytic activity of the strain selected as the best producer of cutinase was assayed with different types of cutin, extracted from apple, papaya and cucumber. Cutin powder (30 $\mathrm{mg}$ ) was added to $0.5 \mathrm{~mL}$ of the culture supernatant and $0.5 \mathrm{~mL}$ of $50 \mathrm{mM}$ phosphate buffer at $\mathrm{pH}$ 7.0. The mixture was then incubated at $30^{\circ} \mathrm{C}$ for 24 hours with agitation at $120 \mathrm{rpm}$. After this period, $0.5 \mathrm{~mL}$ acetic acid and $3 \mathrm{~mL}$ chloroform were added and vigorously shaken until complete phase separation. The chloroform phase was taken, dried, re-suspended in chloroform: methanol (85:15, $\mathrm{v} / \mathrm{v}$ ) and stored for the thin-layer chromatography assay (9).

Thin-layer chromatography of the products from the chemical and enzymatic hydrolysis of cutin

An aliquot $(50 \mu \mathrm{L})$ of each sample was applied to a silica gel G-60 plate. The mobile phase used for the chromatographic assays was composed of diethyl-ether: hexane: absolute acetic acid $(4: 5: 1, \mathrm{v} / \mathrm{v})$. The plate was sprayed with a $0.1 \%$ ethanolic solution of 2',7'-dichlorofluorescein and viewed under UV light (11).

\section{RESULTS AND DISCUSSION}

\section{Isolation and selection of esterase-producer microorganisms}

Of the 400 strains tested, 42 showed esterase activity, using the Triacetin-Rodamin test (1) as described earlier.

\section{Production of Cutin}

Cutin was extracted from various fruits and vegetables, as previously described. The results shown in Table 1 indicate that of the sources tested, Fuji apples provided the highest yield of cutin per gram of peel extract, as previously described in the literature (6). After extraction, the apple cutin became a dry powder, while the cutins from the other sources became emulsions, making them more difficult to handle. In the latter case, lipids extracted together with the cutin from the peels were probably responsible for the formation of emulsions. Apple cutin was the most suitable extract for the development of this study, due to its higher yield and the fact that a dry powder was obtained.

\section{Evaluation of lipase and cutinase production}

Table 2 shows the data for cutinolytic activity obtained with pre-selected esterase-producing strains. As can be seen, the highest cutinolytic activity was observed for strain 180 . The other strains showed little or no cutinolytic activity. Using strain
Table 1. Yield of cutin from the different sources.

\begin{tabular}{ccccc}
\hline Source & $\begin{array}{c}\text { Amount } \\
\text { of peel }(\mathrm{g})\end{array}$ & $\begin{array}{c}\text { Mass of cutin } \\
\text { obtained } \\
(\mathrm{g})\end{array}$ & $\begin{array}{c}\text { Yield } \\
\text { (mg cutin / } \\
\text { g peel })\end{array}$ & $\begin{array}{c}\text { Color of the } \\
\text { resulting } \\
\text { powder }\end{array}$ \\
\hline Fuji Apple & 269.72 & $3.57 \mathrm{~g}$ & 13.12 & Yellow \\
Orange & 200.84 & $0.10 \mathrm{~g}$ & 0.52 & Light brown \\
Papaya & 382.17 & $1.30 \mathrm{~g}$ & 3.40 & orange \\
Cucumber & 188.30 & $0.69 \mathrm{~g}$ & 3.66 & Dark brown \\
\hline
\end{tabular}

Table 2. Lipolytic and cutinolytic activities of esterase-producing strains grown in liquid cutin medium.

\begin{tabular}{ccc}
\hline $\begin{array}{c}\text { Strain } \\
\text { Number }\end{array}$ & $\begin{array}{c}\text { Lipase Activity } \\
(\mu \mathrm{mol} / \mathrm{min} / \mathrm{mL})\end{array}$ & $\begin{array}{c}\text { Cutinase Activity } \\
(\mathrm{nmol} / \mathrm{min} / \mathrm{mL})\end{array}$ \\
\hline 8 & 4.40 & 0 \\
180 & 0.37 & 637.23 \\
283 & 0.37 & 0 \\
298 & 0.37 & 0 \\
308 & 3.66 & 59.57 \\
310 & 4.76 & 176.59 \\
312 & 2.93 & 147.87 \\
323 & 2.93 & 0 \\
338 & 8.06 & 45.21 \\
358 & 1.83 & 136.70 \\
359 & 1.47 & 102.13 \\
368 & 2.20 & 131.38 \\
425 & 0.37 & 0 \\
446 & 1.10 & 0 \\
453 & 1.47 & 0 \\
460 & 0 & 0 \\
461 & 2.20 & 0 \\
469 & 1.47 & 0 \\
\hline
\end{tabular}

180 , cutinase activity similar to that described in literature for bacteria was obtained (6).

The same strains were also inoculated into culture media containing $0.1 \%$ glucose as the sole carbon source, and the cutinolytic activity measured after the fermentation time. These strains showed no cutinolytic activity when grown in such medium.

All the strains pre-selected as esterase positive (using Triacetin-Rodamin medium in Petri dishes), were tested for lipolytic and cutinolytic activity. Table 2 presents both lipolytic and cutinolytic activities obtained with pre-selected esteraseproducing strains, inoculated into the medium containing cutin as the sole carbon source. A comparative analysis was performed in order to differentiate the esterase activity as lipolytic or cutinolytic. 
The strains previously known to be esterase-producing, presented considerable lipolytic activity (activity greater than $1 \mu \mathrm{mol} / \mathrm{min} / \mathrm{mL}$ ) when compared to strains previously known to be lipase-producing. Of the strains tested, six presented lipolytic activity above $4 \mu \mathrm{mol} / \mathrm{min} / \mathrm{mL}$. These data may signify that the esterases found in the novel strains were lipases. It was also observed that strain 180 presented lipolytic activity below 1 $\mu \mathrm{mol} / \mathrm{min} / \mathrm{mL}$, confirming that this strain in fact produces cutinase instead of lipase.

The comparison of data from lipolytic and cutinolytic activity of the strains tested made it possible to identify, among the preselected esterase-producing strains, those producing cutinase, lipase or some other esterase with no lipoytic or cutinolytic activity. Sixteen strains produced another type of esterase. Table 3 presents the data showing lipolytic activity, measured, as previously described, in the supernatant culture medium containing glucose as the carbon source. As can be seen from a comparative analysis of Tables 2 and 3, the lipolytic activity values for each strain grown in both media are very close, showing that the presence of cutin in the culture media has no influence on the production of lipase, despite its important role in the production of cutinase.

\section{Fermentation conditions for cutinase production}

The variables of fermentation time and percentage of cutin in the culture media, were analyzed for strain 180 .

In order to optimize the fermentation time, strain 180 was inoculated into a culture medium containing $0.4 \%$ of cutin, and the cutinase activity determined after 4,6,8,10,12 and 14 days of fermentation. The cutinolytic activity was measured in the supernatant as previously described, and the data are shown in Fig. 1.

Between days 4 and 8 , a decrease in enzymatic activity was observed. From day 8 to day 12 there was an increase in enzymatic activity, with a peak on day 12 . After the $12^{\text {th }}$ day, cutinolytic activity decreased significantly.

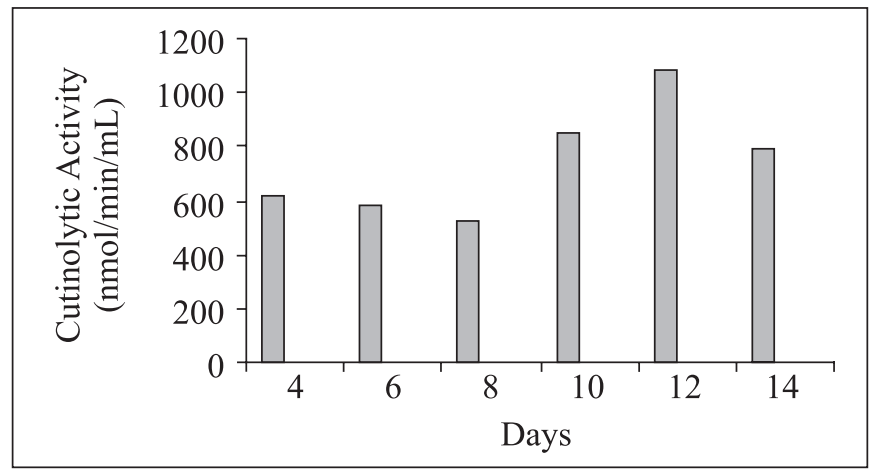

Figure 1. Cutinolytic activity (nmol/min/mL) for strain 180 as a function of fermentation time.
Table 3. Lipase activity in glucose-containing culture medium.

\begin{tabular}{|c|c|}
\hline Strain Number & Activity $(\mu \mathrm{mol} / \mathrm{min} / \mathrm{mL})$ \\
\hline 8 & 4.03 \\
\hline 60 & 4.03 \\
\hline 61 & 4.40 \\
\hline 129 & 6.23 \\
\hline 133 & 0.37 \\
\hline 143 & 0.37 \\
\hline 161 & 0.37 \\
\hline 170 & 1.10 \\
\hline 180 & 0.00 \\
\hline 192 & 1.83 \\
\hline 235 & 0.37 \\
\hline 246 & 0.00 \\
\hline 260 & 6.23 \\
\hline 270 & 0.73 \\
\hline 283 & 0.73 \\
\hline 298 & 0.37 \\
\hline 308 & 0.73 \\
\hline 310 & 0.37 \\
\hline 312 & 0.00 \\
\hline 323 & 0.73 \\
\hline 338 & 7.33 \\
\hline 358 & 0.37 \\
\hline 359 & 0.00 \\
\hline 368 & 0.00 \\
\hline 371 & 0.73 \\
\hline 372 & 3.30 \\
\hline 381 & 0.37 \\
\hline 385 & 0.37 \\
\hline 390 & 0.00 \\
\hline 398 & 0.00 \\
\hline 401 & 0.00 \\
\hline 415 & 1.47 \\
\hline 425 & 1.10 \\
\hline 446 & 1.47 \\
\hline 453 & 0.73 \\
\hline 460 & 0.37 \\
\hline 461 & 0.37 \\
\hline 469 & 0.73 \\
\hline 472 & 0.37 \\
\hline 518 & 0.00 \\
\hline 523 & 0.00 \\
\hline 531 & 0.00 \\
\hline
\end{tabular}

The results regarding the percentage of cutin are shown in Fig. 2. In the range of cutin concentrations used, there was a linearly increasing relationship between the concentration of cutin in the medium and cutinolytic activity. Thus the best conditions for the production of extracellular cutinase were observed using 


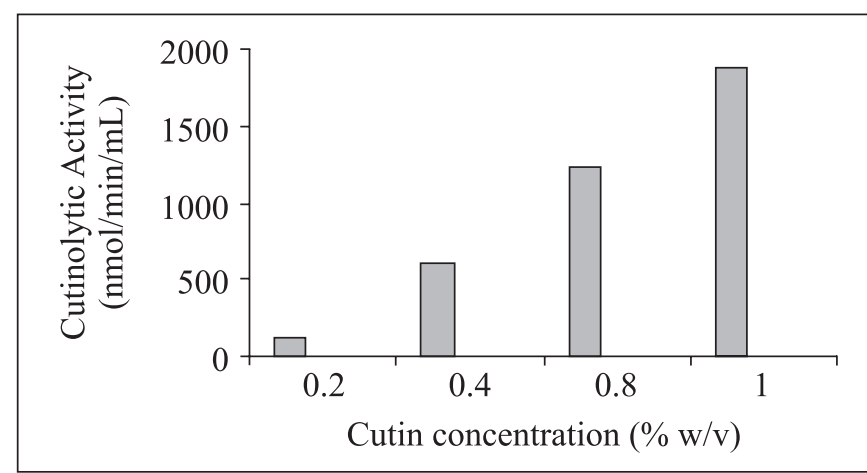

Figure 2. Cutinolytic activity for strain 180 as a function of the amount of cutin added to the fermentation medium.

Strain 180 in a fermentation medium containing $1.0 \%$ cutin (w/v), incubated for 12 days at $30^{\circ} \mathrm{C}$ with shaking at $100 \mathrm{rpm}$.

\section{Chemical and enzymatic hydrolysis of cutin from different sources}

Table 4 shows the amounts of chemically and enzymatically hydrolyzed products obtained from $30 \mathrm{mg}$ of cutin extracted from different sources. Cucumber cutin showed the best yield after chemical hydrolysis, but apple cutin also showed a good amount of hydrolysis products. Orange and Papaya cutins showed much lower yields.

Sources of cutin used for fermentation were: apple, papaya and cucumber. Orange cutin was not tested due to the small amount obtained.

The yield from apple cutin was much greater than from the other cutin sources. Also, the amount of apple cutin hydrolyzed enzymatically was much greater than that obtained chemically, as can be seen in Table 4. These results show that the enzymatic hydrolysis of apple cutin is very efficient. For the other sources of cutin, chemical hydrolysis was more efficient than enzymatic hydrolysis.

Using the data described above, it was possible to determine cutinolytic activity as described by Fett et al. (6) and the results are shown in Table 5. Cutinase activity is far greater in the culture media containing apple cutin.

Table 4. Amounts of products obtained by chemical and enzymatic hydrolysis of $30 \mathrm{mg}$ of cutin from different sources.

\begin{tabular}{ccc}
\hline $\begin{array}{c}\text { Cutin } \\
\text { Source }\end{array}$ & $\begin{array}{c}\text { Chemical } \\
\text { hydrolysis }\end{array}$ & $\begin{array}{c}\text { Enzymatic } \\
\text { hydrolysis }\end{array}$ \\
\hline Apple & $20 \mathrm{mg}$ & $30 \mathrm{mg}$ \\
Orange & $10 \mathrm{mg}$ & 0 \\
Papaya & $16 \mathrm{mg}$ & $2 \mathrm{mg}$ \\
Cucumber & $30 \mathrm{mg}$ & $9 \mathrm{mg}$ \\
\hline
\end{tabular}

Thin-layer Chromatography (TLC) of the products obtained from the chemical and enzymatic hydrolysis of cutin

The products obtained from the chemically hydrolyzed cutin were analyzed by thin layer chromatography (TLC). The results are shown in Fig 3.

An analysis of the TLC plate shows that TLC separated the cutin monomers into diols, triols and tetraols. The presence of these products were observed for comparing the chromatogram obtained by Walton and Kollatukudy (15), using standards. As the number of hydroxyl groups in the monomer increased, so it was held back more in the silica gel layer, silica being a polar substance, resulting in a lower $\mathrm{R}_{\mathrm{f}}$. Unlike the study of Walton and Kollatukudy (15), the presence of monols was not observed.

An interesting result was the separation of the hexadecanotriols from the octadecanotriols, as also observed by Walton and Kollatukudy (15). The major difference between the hydrolyzed cutins from the different sources was the presence of tetraols in apple cutin, these being absent in the other sources. In Fuji apple cutin, besides the presence of tetraols, greater amounts of $\mathrm{C}_{16}$-triols were also present. Few $\mathrm{C}_{18}$-triols and very few diols were observed. In Papaya cutin, greater amounts of diols and $\mathrm{C}_{16}$-triols were found and some $\mathrm{C}_{18}$-triols. In cucumber cutin, there were great amounts of diols and also a strongly polar compound which was not identified (presenting a small $\mathrm{R}_{\mathrm{f}}$ ).

In orange cutin, mainly $\mathrm{C}_{18}$-triols and $\mathrm{C}_{16}$-triols were found, with traces of diols and the same polar compound also observed in cucumber cutin.

Fig. 4 shows the results for the thin-layer chromatography of the enzymatically hydrolyzed cutin products. A considerable decrease in the amounts of diols and $\mathrm{C}_{18}$-triols can be observed as compared to the amounts obtained by chemical hydrolysis (Fig. 3). This was also observed by Fett et al. (6).

\section{CONCLUSIONS}

The organism selected and isolated as the best producer of cutinase was identified by Fundação de Pesquisas Tropical André Tosello, as Fusarium oxysporum (strain 180), an organism previously known to be a cutinase producer, as described in

Table 5. Cutinase activity produced which was strain used in media containing cutin from different sources.

\begin{tabular}{cc}
\hline Cutin Source & $\begin{array}{c}\text { Cutinolytic Activity } \\
\text { (mg of monomers released / } \\
\text { 24 hours/mL of supernatant) }\end{array}$ \\
\hline Apple & 60 \\
Papaya & 4 \\
Cucumber & 18 \\
\hline
\end{tabular}




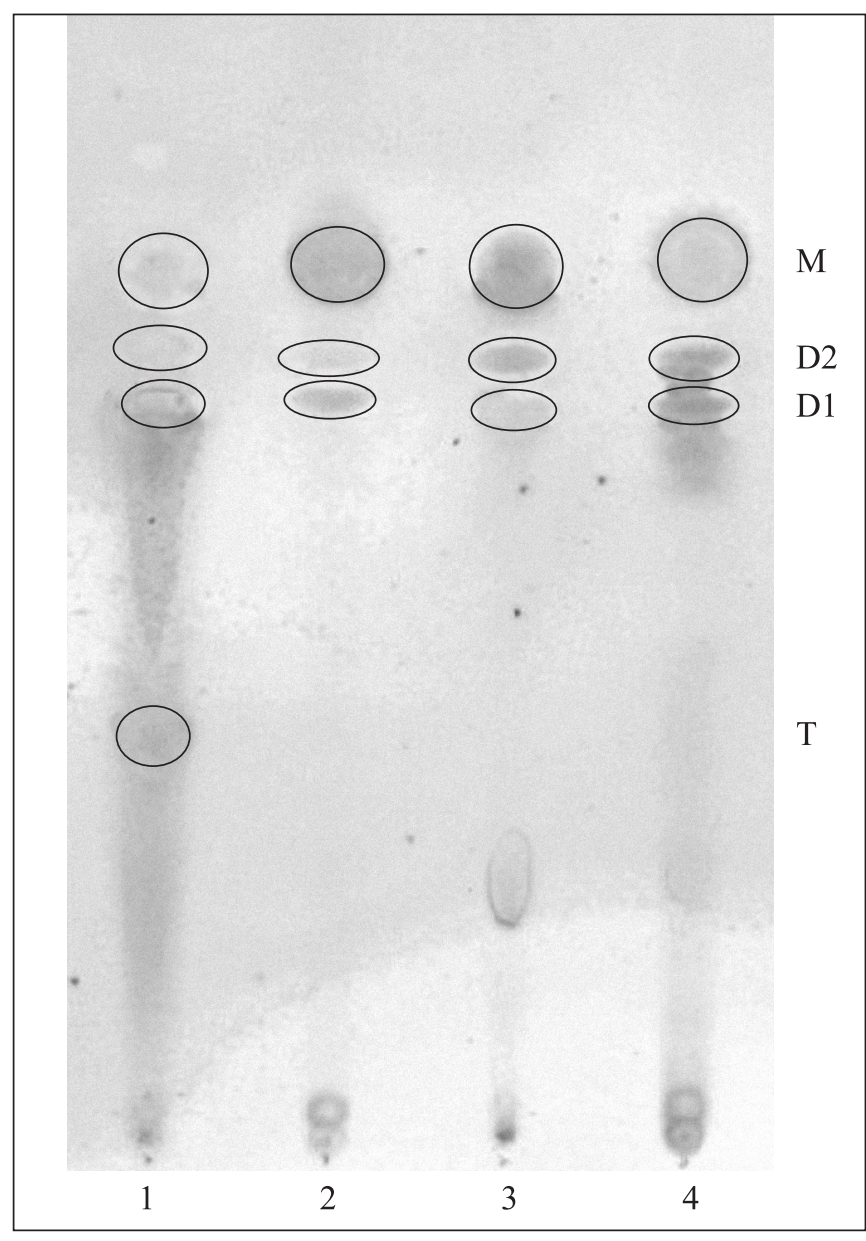

Figure 3. Chemically hydrolyzed cutin products.

1-Fuji Apple;

2-Papaya;

3-Caipira Cucumber;

4- Orange.

M:diols;

$\mathrm{D}_{2}: \mathrm{C}_{18}$-triols;

$\mathrm{D}_{1}: \mathrm{C}_{16}$-triols;

T-tetraols.

literature. This strain showed reduced lipolytic activity, confirming that it produces cutinase instead of lipase.

For all the strains tested, the values for lipolytic activity were very close when grown in media containing either glucose or cutin as the sole source of carbon. This highlights the fact that the presence of cutin in the culture medium has no influence on the production of lipase, in contrast to its important role in the production of cutinase.

Using strain 180, the best conditions for the production of extracellular cutinase were observed in a fermentation medium containing $1 \%$ cutin (w/v), incubating for 12 days at $30^{\circ} \mathrm{C}$ and

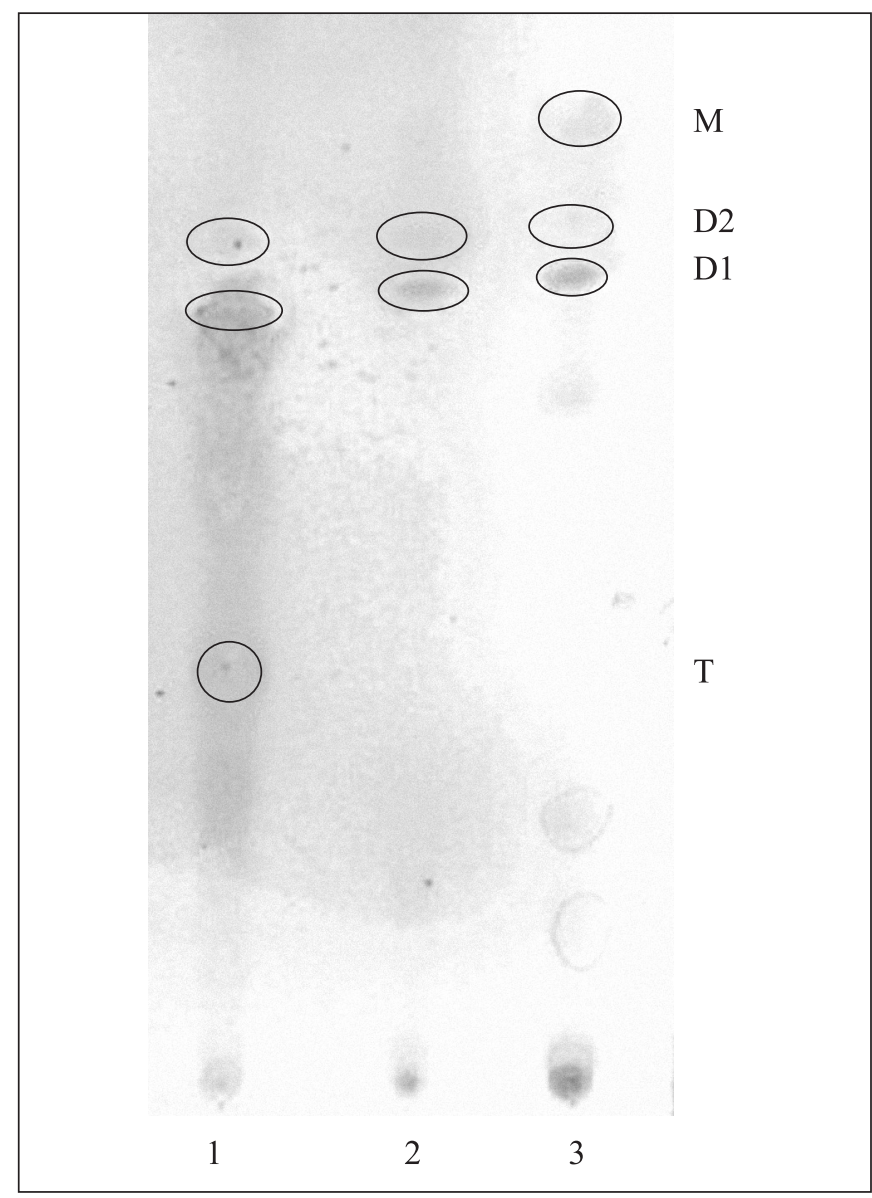

Figure 4. Thin-layer Chromatography of enzymatically hydrolyzed cutin products.

1-Fuji Apple;

2-Papaya;

3-Caipira Cucumber;

M:diols;

$\mathrm{D}_{2}: \mathrm{C}_{18}$-triols;

$\mathrm{D}_{1}: \mathrm{C}_{16}$-triols;

T-tetraols.

$100 \mathrm{rpm}$. The characteristics of the cutinase produced were different from those cited in literature and deserve further studies for a better characterization.

\section{RESUMO}

\section{Seleção de microorganismos produtores de cutinase}

A cutinase pertence, como as lípases, ao grupo das esterases (EC 3.1.1.X), que são enzimas capazes de catalisar reações de hidrólise de ligações do tipo éster. A cutinase catalisa a hidrólise da cutina, um biopoliéster insolúvel que constitui o componente 
estrutural da cutícula das plantas. Esta enzima tem se mostrado um eficiente catalisador tanto em solução aquosa quanto em meios orgânicos, sendo potencialmente apropriada para usos em indústria de detergentes, alimentos e cosméticos. O objetivo deste trabalho foi isolar fungos de diversas fontes e realizar uma pré-seleção destes, quanto à habilidade em produzir esterase. As linhagens fúngicas pré-selecionadas como produtoras de esterase foram inoculadas em meio de cultivo contendo cutina extraída de maçã. As atividades cutinolítica e lipolítica foram medidas no sobrenadante das culturas a fim de diferenciar os microrganismos produtores de lipase dos produtores de cutinase. Uma linhagem isolada mostrou a maior atividade cutinolítica após 12 dias de fermentação em um meio contendo $1 \%$ de cutina e foi identificada como sendo o Fusarium oxysporium.

Palavras-chave: cutinase, esterases, enzimas microbianas, seleção

\section{REFERENCES}

1. Bornscheuer, U.T. Microbial carboxyl esterases: classification, properties and application in biocatalysis. FEMS Microbiol. Rev., 26, 73-81, 2002.

2. Calado, C.R.C.; Monteiro, S.M.S.; Cabral, J.M.S.; Fonseca, L.P. Effect of pre-fermentation on the production of cutinase by a recombinant Saccharomyces cerevisiae. J. Biosc. Bioeng., 93, 354-359, 2002.

3. Carvalho, C.M.L.; Aires-Barros, M.R.; Cabral, J.M.S. Cutinase: From molecular level to bioprocess development. Biotechnol. Bioeng., 66, 17-34, 1999.
4. Egmond, M.R.; Vlieg, J. Fusarium solani pisi cutinase. Biochimie, 82, 1015-1021, 2000.

5. Fett, W.F.; Gerard, H.C.; Moreau, R.A.; Osman, S.F.; Jones, L.E. Cutinase Production by Streptomyces spp. Curr. Microbiol., 25, 165-171, 1992.

6. Fett, W.F.; Gerard, H.C.; Moreau, R.A.; Osman, S.F.; Jones, L.E. Screening of nonfilamentous bacteria for production of cutin-degrading enzymes. Appl. Environm. Microbiol., 58, 2123-2130, 1992.

7. Fett, W.F.; Wijey, C.; Moreau, R.A.; Osman, S.F. Production of cutinase by Thermomonospora fusca ATCC 27730. J. Appl. Microbiol., 86, 561-568, 1999.

8. Gerard H.C.; Fett W.T.; Osman S.F. Evaluation of cutinase activity of various industrial lipases. Biotechnol. Appl. Biochem., 17, 181190,1993

9. Kolattukudy, P.E.; Purdy, R.E.; Maiti, I.B. Cutinases from fungi and pollen. Meth. Enzymol., 71, 652-664, 1981.

10. Koller, W.; Parker, D.M. Purification and characterization of cutinase from Venturia inaequalis. Phytopatology, 79, 278-283, 1989.

11. Lin, T.S.; Kolattukudy, P.E. Induction of a biopolyester hydrolase (cutinase) by low level of cutin monomers in Fusarium solani f. sp. pisi. J. Bacteriol., 133, 942-951, 1978.

12. Macedo, G.A.; Pastore, G.M. Lipases microbianas na produção de ésteres formadores de aroma. Rev. Soc. Bras. Ciência Tecnol. Alim., 17, 115-119, 1997.

13. Melo, E.P.; Baptista, R.P.; Cabral, J.M.S. Improving cutinase stability in aqueous solution and in reverse micelles by media engineering. $J$. Molec. Catal. B: Enzimatic, 22, 299-306, 2003.

14. http://www.nal.usda.gov/ttic/tektran/data.html, 30/01/2005.

15. Walton, T.J.; Kolattukudy, P.E. Determination of the strutures of cutin monomers by a novel depolymerization procedure and combined gas chromatography and mass spectrometry. Biochemistry, 11, 18851896, 1972.

16. Trail, F.; Koller, W. Diversity of cutinases from plant pathogenic fungi: purification and characterization of two cutinases from Alternaria brassicicola. Physiol. Molec. Plant Pathol., 42, 205220, 1993. 